\title{
An Analytical Study of Final Stages Biokinematic Characteristics of some Compound Skill Performances of Young Soccer
}

Dr. Mohamed Dahy Abbas'

Prof. Dr. Tarek Mohamed Gaber ${ }^{r}$

Introduction \& Research

Problem

A compound skillful movement performance is generally successive, synchronic, or illusive, as compound successive skill performance includes a combination of skill performances according to time succession, whereas compound synchronic motor performance merges skill performances synchronically in a way that does not clarify succession among them, and the compound illusive skill performance is a preliminary stage that leads to a reaction of the opponent, and near the end of the preliminary stage, a player makes a sudden shift of movement path into a main stage of a new skill performance, without a preliminary stage (1): 1 ).
An instructor and trainer can recognize the ideal form of performance and how to teach it, through steps of motor analysis of compound skill movement performance, in addition to recognizing the limits of compound skill movement performance in order to achieve ideal performance, and accomplish mechanic duty with the highest possible efficiency, leading to a positive effect on level of performance, and reaching the best results in competitions, since biomechanical analysis is used to recognize specific skill principles, rules, and facts, as an approach to diagnosis, instructing, and improving players' performance, in comparison with the analyzed

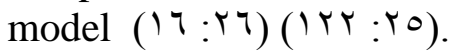

The dual stage that is considered the most important stage that was conducted by the

\footnotetext{
${ }^{1}$ Associate Professor, Faculty of Physical Education - King Faisal University, Kingdom of Saudi Arabia.

${ }^{2}$ Professor of soccer at Dept. of Curricula \& Instruction - Faculty of Physical Education - Assuit University.
} 
current researchers so as to recognize the most important stage involved in achieving basic mechanic duty of compound motor performances, as it was found that $77.8 \%$ of experts agreed that the dual stage is the most important stage involved in achieving basic mechanic duty of compound motor performances, whereas $11.1 \%$ stated that the preliminary stage is the most important one, and $11.1 \%$ stated that the final stage is the most important stage involved in achieving basic mechanic duty. the biomechanical variables is found to be the effective factor in reducing the time structure of compound skill performances, hence, , in which the two skills will be combined together.

\section{Aim of the Research:}

The present research aims at recognizing the biomechanical characteristics of final stages of some compound skill performances for young soccer's through: recognizing the values of biomechanical variables (speed - displacement - path of body

\section{Table (1)}

Means of physical traits of the research sample weight - body angles - angular speed of body points) that affect compound skill performance stages (reception by inside foot - direct shooting while moving by front foot).

\section{Research questions:}

There are significant characteristics and values of biomechanical variables (speed - displacement - path of body weight - body angles - angular speed of body points) of compound skill performance stages (reception by inside foot - direct shooting while moving by front foot) of young soccer's.

\section{The Research Population \&} Sample:

The research population was selected from young soccer at the age stage (12 14) at Sohag Sporting Club during the training season 2017 - 2018 whose number was (25) young soccer. However, some players were excluded (8), (2) absent, (2) injured, (10) for the pilot study. the research population comprised (7) young soccer that chosen as a purposeful sample to conduct the study. 


\begin{tabular}{|c|c|c|}
\hline Trait & Unit of Measurement & Data \\
\hline Height & $\mathrm{Cm}$. & $1 \leqslant \Lambda . \leqslant Y q$ \\
\hline Weight & Kgm. & $\varepsilon \cdot .7 Y 7$ \\
\hline Trunk & $\mathrm{Cm}$. & $V \cdot . O Y \leq$ \\
\hline Arm & $\mathrm{Cm}$. & $V \cdot . \wedge 0 \leq$ \\
\hline Upper Arm & $\mathrm{Cm}$. & rq. $\leqslant \wedge r$ \\
\hline Forearm & $\mathrm{Cm}$. & YY.Y . \\
\hline Hand & $\mathrm{Cm}$. & $1 \vee . \wedge 9 \varepsilon$ \\
\hline Leg & $\mathrm{Cm}$. & $\wedge 9.0 \ldots$ \\
\hline Thigh & $\mathrm{Cm}$. & $\leqslant \leqslant .0 \ldots$ \\
\hline Calf & $\mathrm{Cm}$. & $\varepsilon \cdot .0 \ldots$ \\
\hline Foot & $\mathrm{Cm}$. & r.. ro \\
\hline
\end{tabular}

\section{Harmony of Research Sample}

The researchers affirmed harmony among the research population before video and biomechanical motor analysis

Table (2)

Arithmetic means, median, standard deviation, and skewness of the main variables of research population $N=(17)$

\begin{tabular}{|c|c|c|c|c|}
\hline Skewness & $\begin{array}{l}\text { Standard } \\
\text { Deviation }\end{array}$ & Median & $\begin{array}{c}\text { Arithmetic } \\
\text { means }\end{array}$ & Variables \\
\hline $.00 Y_{-}$ & $\varepsilon .7 V \varepsilon$ & $1 \leq 9 . \ldots$ & $1 \leq \wedge . Y 9 \leqslant$ & Height \\
\hline$\because .19$ & $\varepsilon .9 T r$ & $\sum 1 . .$. & $\varepsilon . .10$ & Weight \\
\hline$\cdot Y Y Y_{-}$ & 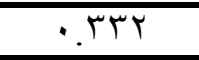 & $11.0 \ldots$ & 11.705 & Age \\
\hline $.09 r_{-}$ & $\because$ YYO & r... & $1 . \Lambda 1 \pi$ & Training Age \\
\hline
\end{tabular}

Table (2) indicates that the values of skewness coefficients ranged between ( $\left.. r \leqslant V_{-} \cdot . \wedge T \leqslant\right)$. This signifies that the sample measurements in variable of age and training age came under the normal distribution curve, which is a reference to the harmony of in variables that might affect the research results as demonstrated in the following table: sample individuals in theses variables.

Procedures of the Research Specifying Compound Skill Performances

The researchers specified the compound skill performances of the highest frequency during matches, according to what 
was stated by many researchers and specialists in their literature through making a comprehensive referential survey (appendix 1), then, they piloted the experts' opinion concerning the recognition of compound skill performances of the highest frequency during matches, in addition to specifying compound skill performances that are most appropriate for the age stage of the research sample (12-14) years.. Shooting while moving by foot front, and ball reception passing by inside foot, were selected according to their importance among experts who stated with a $100 \%$ percentage that they are the most appropriate for the age stage of the research sample.

Techniques \& Tools of Gathering Data

Tools \& Equipment Used in the Research

- 3 video cameras with frequency 250 cadre/second and a triple stand

- A digital camera with 4 gigabytes internal memory and frequency 30 cadre/second

- An electronic memory for storing videos

- Phosphoric signs to specify body joints in circular form of $3 \mathrm{~cm}$. width having a black circle in the middle
- Electrical wires of 100 meters length

- A measurement cube 1 X 1 meter - a measurement tape $-\mathrm{a}$ computer set for unit of motor analysis

- Phosphoric ground for specifying and demonstrating movement range

- Dark uniform to suit video background

- Motor analysis program (Simi Motion) which is one of the newest high definition computer software

\section{The Main Study}

After specifying the study approach, sample, tools of data gathering, and conducting the pilot study, the compound skill performances of the current research were also defined, as well as points of time that will be dealt with within the study. The main study and experiment were conducted as follows:

\section{Video Procedures}

After specifying the compound skill performances and time points that would be dealt with in the current study, the researchers made a video of one trial for each player that was later biomechanically analyzed (appendix 7).

Preparing the Video Setting 
The researchers specified the range within which the skill would be performed in order to limit the video range through guiding signs and camera positions.
Camera positions were adapted for video setting and range of motion, at a distance of 11.75 meters, and 1.15 meter height, assuring that the video cadre included the whole range of

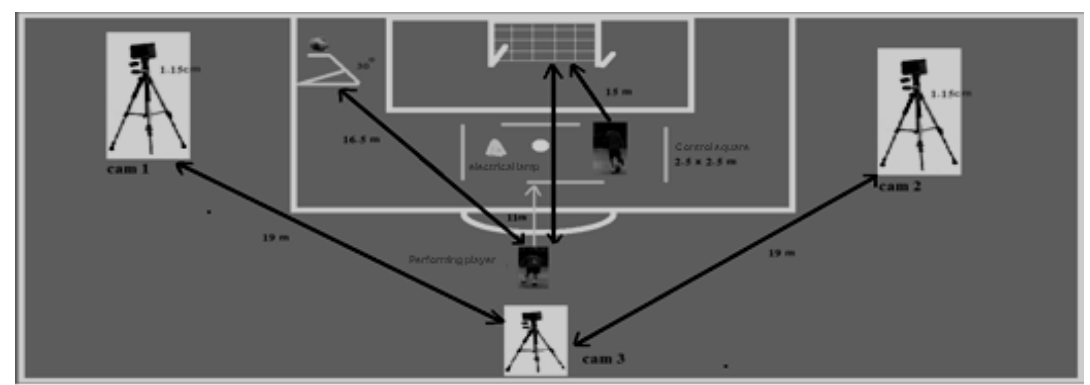

Preparing Camera Position

motion.

Figure (1)

Camera position during video of current research skills

\section{Preparing Players for Video}

Sticker signs were put on the anatomical points of players' body joints, where similar points to head weight center were specified above lateral border of the anconeus muscle, cubitus joint was represented by a point on the humerus bone, shoulder joint was represented by a point on the scapula extrusion, , thigh joint represented by a point on the big rotator of the femur, knee joint was represented by a point above the lower condyle of femur, and the ankle represented by a point on the fibula, and the metatarsal bones.

\section{Procedures of Biomechanical}

\section{Motor Analysis}

The process of biomechanical motor analysis was performed at the biomechanical motor analysis laboratory at the Faculty of Physical Education, Assuit University, Trials were arranged according to video processing procedures. The number of analyzed trials was (7), one for each player, and biomechanical variables of the study were extracted using Simi Motion program. Raw 
data were introduced in order to calculate (speed displacement - velocity). Statistical treatment was conducted for raw data resulted from biomechanical motor analysis through SPSS

program.

\section{Results \& Discussion}

Results and discussion of the time variable (time structure of the research compound skill performances):

Table (3)

Time structure and percentage of each stage of compound skill performance Ball reception and passing with inside of foot

\begin{tabular}{|c|c|c|c|}
\hline $\begin{array}{c}\text { Stage percentage } \\
\text { to total time }\end{array}$ & $\begin{array}{c}\text { Stage time } \\
\text { (sec.) }\end{array}$ & Stage & $\overline{\mathbf{N}}$ \\
\hline$\% \wedge$. & Y. . $9 \leq$ & $\begin{array}{l}\text { Running time befor } \\
\text { reception }\end{array}$ & 1 \\
\hline$\%$ r. & $.7 V V$ & Time of dual stage & r \\
\hline$\%$ & r. $\varepsilon V$ & Total time & $r$ \\
\hline \multicolumn{4}{|c|}{$\begin{array}{ll}\text { Table (3) indicates that } & \text { and passing"), running time } \\
\text { the total time of performing } & \text { before reception was }(2.794) \\
\text { ball reception and passing with } & \text { sec. with a percentage of } 80 \% \\
\text { inside of foot was }(3.471) \text { sec. } & \text { of the total time of } \\
\text { and the researchers divided } & \text { performance, and the dual } \\
\text { performance into two essential } & \text { stage (between reception and } \\
\text { stages (running time before } & \text { passing) was (0.677) sec. with } \\
\text { reception, and time of dual } & \text { a percentage of } 20 \% \text { of the } \\
\text { stage "time between reception } & \text { total time of performance. }\end{array}$} \\
\hline \multicolumn{4}{|c|}{$\begin{array}{l}\text { Table (4) } \\
\text { rcentage of du }\end{array}$} \\
\hline $\begin{array}{c}\text { Stage percentage } t \\
\text { total time }\end{array}$ & $\begin{array}{c}\begin{array}{c}\text { Stage time } \\
\text { (sec.) }\end{array} \\
\end{array}$ & Stage & $\overline{\mathbf{N}}$. \\
\hline$\% \leqslant \varepsilon r$ & $\because \cdot r$ & Reception time & 1 \\
\hline$\% \wedge r . \wedge \vee$ &. .071 & Rotation time & r \\
\hline$\% 0.91$ & $\because \cdot \varepsilon \cdot$ & Swinging time & T \\
\hline$\% 7 . \vee 9$ & $\because \cdot \leqslant 7$ & Passing time & $\varepsilon$ \\
\hline$\% 1 \cdots$ & $.7 \mathrm{VV}$ & Total time & 0 \\
\hline
\end{tabular}


Table (4) shows that the time of dual stage of performing ball reception and passing with inside of foot was (0.677) sec., and the researchers divided it into four stages (reception time, rotation time, swinging time, and passing time): reception time was (0.030) sec., with a percentage $(\% \leqslant . \leqslant \mu)$ of the dual stage time, rotation time

\section{Table (5)}

Time structure and percentage for each of compound skill stages Direct shooting while moving by foot front

\begin{tabular}{|c|c|c|c|}
\hline $\begin{array}{c}\text { Stage percentage of } \\
\text { total time }\end{array}$ & $\begin{array}{c}\text { Stage time } \\
\text { (sec.) }\end{array}$ & Stage & N. \\
\hline$\% 97$ & r.A. $q$ & $\begin{array}{c}\text { Running time before } \\
\text { shooting }\end{array}$ & 1 \\
\hline$\% \varepsilon$ & $.11 \mathrm{~V}$ & Time of dual stage & $r$ \\
\hline$\% 1 \ldots$ & Y.9Y7 & Total time & $r$ \\
\hline
\end{tabular}

Table (5) indicates that total time of performance of direct shooting while moving by foot front was (2.926) sec., and the researchers divided performance into two essential stages: (running time before shooting, and dual stage time "time from ball touching till was (0.561) sec., with a percentage $(\% \wedge r . \wedge \vee)$ of the dual stage time, swinging time was (0.040) sec., with a percentage $\mathbf{5 . 9 1 \%}$ ) of the dual stage time, and passing time was (0.046) sec., with a percentage $\left(\% \overline{\%} \vee^{9}\right)$ of the dual stage time (time from reception to end of performance). 
of $(4 \%)$ of total performance time. 
Table (6)

Time structure and percentage of dual stage of compound skill performance Direct shooting while moving

\begin{tabular}{c|c|c|c}
\hline \hline $\begin{array}{c}\text { Stage percentage to } \\
\text { total time }\end{array}$ & Stage time (sec.) & stage & N. \\
\hline \hline$\% \vee r$ & $\ddots \wedge \varepsilon$ & Swinging time & $\checkmark$ \\
\hline$\% \curlyvee \wedge$ & $\ddots \cdot r r$ & Shooting time & $r$ \\
\hline$\% \uparrow \cdots$ & $\ddots .1 \vee$ & Total time & $r$ \\
\hline \hline
\end{tabular}

Table (6) shows that dual stage time of performing direct shooting while moving was (0.117) sec. The researchers divided it into two stages (swinging time, and shooting time). The swinging time was (0.084) sec. with a percentage $(72 \%)$ of dual stage time, and the shooting time was (0.033) sec. with a percentage $(28 \%)$ of dual stage time (time from ball touching till the end of performance).

Presentation and discussion of results of speed variable values for anatomical points during selected time moments of research compound skill performances 
Table (7)

Arithmetic mean, standard deviation, and highest/lowest values of speed variable values for anatomical points during selected time moments of compound skill performance (Ball reception and passing with inside of foot) 
Table (8)

Arithmetic mean, standard deviation, and highest/lowest values of speed variable values for anatomical points during selected time moments of compound skill performance (direct shooting while moving by foot front) 
Table (7) shows that the highest horizontal speed was for the right foot toe $(7.364 \mathrm{~m}$. /sec.), and the lowest horizontal speed was for the right ankle (-1.208 m./ sec.). The highest tangential speed was for right foot toe $(7.382 \mathrm{~m}$. / sec.), and the lowest tangential speed was for the right thigh $(0.250 \mathrm{~m}$. / sec.). The highest vertical speed was for right knee $(0.262 \mathrm{~m}$. sec.), whereas the lowest vertical speed was for right knee $\left(\begin{array}{ll}-0.874 \quad \mathrm{~m} . / \mathrm{sec} .\end{array}\right) \quad$ during reception moment of compound skill performance into passing with inside foot. Table (8) indicates that the highest horizontal speed value was for the right foot toe (12.413) m./ sec. and the lowest value was for right ankle (1.551) m./ sec., the highest tangential speed was for right foot toe (8.199) $\mathrm{m}$. / sec. and its lowest value was for right ankle (-0.520) m. / sec., whereas the highest vertical speed was for right knee $(0.885) \mathrm{m} . / \mathrm{sec}$. and the lowest vertical speed was for right ankle (-5.782) m./ sec. during maximal swinging of compound skill performance, direct shooting while moving. The table also indicates that the highest value of horizontal speed was for right foot toe (13.839) m./ sec., and its lowest value was for right thigh (0.127) m./ sec., the highest tangential speed was for right foot toe $(4.151) \mathrm{m}$. / sec., and its lowest value was for right ankle (-0.890) m./ sec., whereas the highest vertical speed was for right knee (1.561) m./ sec., and its lowest value was for right ankle (-4.851) m./ sec., during collision moment of compound skill performance, direct shooting while moving. In addition, table (8) shows that the highest horizontal speed was for right ankle (8.759) $\mathrm{m}$. / sec., the lowest horizontal speed was for right thigh (-0.382), the highest tangential speed was for right foot toe (7.430), the lowest tangential speed was for right thigh 
(-0.271), the highest vertical speed was for right knee (0.975), and the lowest vertical speed was for right foot ankle (-2.923) during the swinging moment of compound skill performance, reception and passing with inside foot. Finally, the table indicates that the highest horizontal speed was for right ankle $(6.432 \mathrm{~m}$. / sec.), the lowest horizontal speed was for right thigh (0.115 m. / sec.), the highest tangential speed was for right foot toe (5.005), the lowest tangential speed was for right thigh $(-0.255 \mathrm{~m} . / \mathrm{sec}$.$) , the$ highest vertical speed was for right foot toe $(2.047 \mathrm{~m}$. / sec.), and the lowest vertical speed was for right ankle $(-1.424 \mathrm{~m}$. / sec.) during passing moment of compound skill performance, reception and passing with inside foot.

Presentation of results of displacement variable values for anatomical points during selected time moments of research compound skill performances 
Table (9)

Arithmetic mean, standard deviation, and highest/lowest values of displacement variable values for anatomical points during selected time moments of compound skill performance (Ball reception and passing with inside of foot) 
Table (10)

Arithmetic mean, standard deviation, and highest/lowest values of displacement variable values for right lower limb during maximal swinging moment of compound skill performance (direct shooting while moving by foot front)

\begin{tabular}{|c|c|}
\hline & \\
\hline $\begin{array}{l}\text { Presentation } \\
\text { scussion of results of } \\
\text { omechanical variable values }\end{array}$ & $\begin{array}{l}\text { selected time moments of } \\
\text { research compound skill } \\
\text { performances }\end{array}$ \\
\hline
\end{tabular}
for body mass center during 
Table (11)

Arithmetic mean, standard deviation, and highest/lowest values of body mass center during selected time moments of compound skill performance (Ball reception and passing with inside of foot) 
Table (11) demonstrates the biomechanical variables of body mass center during selected time moments of compound skill performance, reception and passing with inside foot. During the reception moment, the highest horizontal displacement was $\left(\begin{array}{ll}1.865 & \mathrm{~m}\end{array}\right)$, the lowest horizontal displacement was (0.769 cm.), the highest tangential displacement was $(1.504 \mathrm{~cm}$.$) , the lowest$ tangential displacement was $(0.879 \mathrm{~cm}$.$) , the highest$ vertical displacement was $(0.868 \mathrm{~cm}$.$) , and the lowest$ vertical displacement was $(0.700 \mathrm{~cm}$.$) . The highest$ horizontal speed was $(1.487 \mathrm{~m}$. / sec.), the lowest horizontal speed was $(0.990 \mathrm{~m}$. / sec.), the highest tangential speed was $(0.990 \mathrm{~m} . / \mathrm{sec}$.$) , the lowest$ tangential speed was $(0.314 \mathrm{~m}$. / sec.), the highest vertical speed was (0.314 m. / sec.), and the lowest vertical speed was (-0.247 m. / sec.). During the swinging moment, the highest horizontal displacement was $(2.252) \mathrm{cm}$., the lowest horizontal displacement was (1.309) cm., the highest tangential displacement was $(2.051) \mathrm{cm}$., the lowest tangential displacement was $(1.150) \mathrm{cm}$., the highest vertical displacement was $(0.824) \mathrm{cm}$., and the lowest vertical displacement was $(0.707) \mathrm{cm}$. The highest horizontal speed was (1.143) m./sec., the lowest horizontal speed was (0.396) m./sec., the highest tangential speed was (1.336) m./sec., the lowest tangential speed was (0.143) m./sec., the highest vertical speed was (0.078) $\mathrm{m} . / \mathrm{sec}$., and the lowest vertical speed was (-0.605) m./sec. During the passing moment, the highest horizontal displacement was $(2.293) \mathrm{cm}$., the lowest horizontal displacement was $(1.333) \mathrm{cm}$., the highest tangential displacement was $(2.104) \mathrm{cm}$., the lowest tangential dis placement was $(1.157) \mathrm{cm}$., the highest vertical displacement was (0.829) cm., and the lowest vertical displacement was $(0.697) \mathrm{cm}$. The highest horizontal speed was (0.941) m./sec., the lowest horizontal speed was (0.080) m./sec., the highest tangential speed was (1.250) m./sec., the lowest tangential speed was (0.279) $\mathrm{m} . / \mathrm{sec}$, the highest vertical speed was $(0.435) \mathrm{m} . / \mathrm{sec}$., and the lowest vertical speed was ($0.558) \mathrm{m} . / \mathrm{sec}$., for body mass center during the passing moment of compound skill performance, reception and passing with inside foot. 
Table (12)

Arithmetic mean, standard deviation, and highest/lowest values of body mass center variables during maximal swinging moment of compound skill performance (direct shooting while moving by

foot front)

\begin{tabular}{|c|c|c|c|c|c|c|c|c|}
\hline \multicolumn{4}{|c|}{ Collision moment } & \multicolumn{5}{|c|}{ Maximal swinging moment } \\
\hline $\begin{array}{l}\text { Lowest } \\
\text { value }\end{array}$ & $\begin{array}{l}\text { Highest } \\
\text { value }\end{array}$ & $\varepsilon^{ \pm}$ & س- & $\begin{array}{c}\text { Lowest } \\
\text { value }\end{array}$ & $\begin{array}{c}\text { Highest } \\
\text { value }\end{array}$ & $\varepsilon^{ \pm}$ & س- & variables \\
\hline $1.1 \wedge \mu$ & $r .091$ & $9 . .17$ & 1.109 & 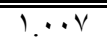 & $\overline{r . r V O}$ & $\cdot r q$. & 1.097 & Horizontal displacement \\
\hline$\cdot r \wedge \varepsilon$ & 1.1799 & $\cdot . \varepsilon \mu \Lambda$ & 1.100 & . TYT & $1.77 \varepsilon$ & $\cdot . \Sigma 1 \%$ & $1.1 \leqslant r$ & Tangential displacement \\
\hline. .171 & $\cdot$. ATY & $\because \Gamma \wedge$ &. .117 & $\because \vee V \varepsilon$ & $\because 10$ & $\because . Y T$ & $\cdot \wedge \cdot \wedge$ & Vertical displacement \\
\hline $1 . \leqslant \leqslant Y$ & t.ITT & $\cdot r \cdot Y$ & $1 . V 7 \mathrm{~V}$ & 1.471 & r.r.乏 & $\cdot .197$ & 1.190 & Horizontal speed \\
\hline. .114 & $1.1 \mathrm{VT}$ & $\cdot r v$. & $\because$ VYO & $\because \times q_{-}$ & $1 . r V$ & $\cdot . \varepsilon \cdot 0$ & .797 & Tangential speed \\
\hline$\because \cdot \mu \wedge$ & eVt. & $\cdot r \leqslant 9$ & - MYY & •. $29 Y_{-}$ & $\cdot r \leqslant \cdot$ & $\cdot r \mu V$ & $.1 \leqslant \Lambda_{-}$ & Vertical speed \\
\hline
\end{tabular}

Table (12) indicates the values of biomechanical variables of body mass center during time moments of compound skill performance, direct shooting while moving with foot front. During the moment of maximal swinging, the highest horizontal displacement was $(2.375) \mathrm{cm}$, the lowest value of horizontal displacement was (1.007) $\mathrm{cm}$., the highest value of tangential displacement was $(1.664) \mathrm{cm}$., the lowest value of tangential displacement was (0.323) $\mathrm{m} . / \mathrm{sec}$, the highest value of vertical displacement was $(0.850) \mathrm{cm}$., and the lowest value of vertical displacement was $(0.774) \mathrm{cm}$. The highest value of horizontal speed was (2.304) m./sec., the lowest value of horizontal speed was
(1.261) m./sec., the highest value of tangential speed was (1.037)m./sec., the lowest value of tangential speed was (0.029) m./sec., the highest value of vertical speed was (0.340) m./sec., and the lowest value of vertical speed was (0.492) $\mathrm{m} . / \mathrm{sec}$., for body mass center, during the maximal swinging moment of time. During collision moment, the highest value of horizontal displacement was $(2.591) \mathrm{cm}$., the lowest value of horizontal displacement was $(1.183) \mathrm{cm}$., the highest value of tangential displacement was (1.779) cm., the lowest value of tangential displacement was $(0.384) \mathrm{cm}$., the highest value of vertical displacement was $(0.862) \mathrm{cm}$., and the lowest value of vertical displacement was $(0.761) \mathrm{cm}$. 
The highest value of horizontal speed was (2.123) m./sec., the lowest value of horizontal speed was (1.442) m./sec., the highest value of tangential speed was (1.173) m./sec., the lowest value of tangential speed was (0.136) m./sec., and the highest value of vertical speed was (0.720) m./sec., and the lowest value of vertical

\section{Table (13)}

Arithmetic mean, standard deviation, and highest/lowest values of body angles during the time moment of reception for compound skill performance (Ball reception and passing)

\begin{tabular}{|c|c|c|c|c|c|c|c|c|c|c|c|c|}
\hline \multicolumn{4}{|c|}{ Passing moment } & \multicolumn{4}{|c|}{ Swinging moment } & \multicolumn{4}{|c|}{ Reception moment } & \multirow{2}{*}{$\begin{array}{c}\text { Time moments } \\
\begin{array}{c}\text { Anatomical } \\
\text { points }\end{array}\end{array}$} \\
\hline $\begin{array}{c}\text { Lowest } \\
\text { value }\end{array}$ & $\begin{array}{c}\text { Highest } \\
\text { value }\end{array}$ & $\varepsilon^{ \pm}$ & س- & $\begin{array}{c}\text { Lowest } \\
\text { value }\end{array}$ & $\begin{array}{c}\text { Highest } \\
\text { value }\end{array}$ & $\varepsilon^{ \pm}$ & س- & $\begin{array}{c}\text { Lowest } \\
\text { value }\end{array}$ & $\begin{array}{c}\text { Highest } \\
\text { value }\end{array}$ & $\varepsilon^{ \pm}$ & س- & \\
\hline $11 \mathrm{~V} .7 .8$ & $101 . r \leq r$ & 11. ror & ITr.Y $\leq V$ & IrT.Y & 107.01. & $11 . r .0$ & $1 r v .01$ & 1.7 .40 & 171.111 & $r . \cdot r \varepsilon$ & צדי.דזו & Right thigh angle \\
\hline $1 \cdot v . \varepsilon \cdot 1$ & $1 \leq 1 . v \leq$ & $1 \leq r v 1$ & $1+7.101$ & $91 .+1 \leq$ & 109.711 & 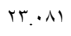 & 110.5. & $9 \varepsilon . \varepsilon \cdot T$ & IVT.091 & ri.iv. & $1 \leq . .1 \%$. & Right knee angle \\
\hline $99 . \vee 9 \leqslant$ & $11 \leq .+Y \Lambda$ & $\leqslant \leqslant r V$ & 1.V.rrq & I. rro & $1 T \cdot 90 r$ & $V 1.7 T$ & $1 \cdot 1 . \leqslant 0$. & $90.7 \leqslant 7$ & 10r.rki & r.T. $T$ & 110.197 & Right foot angle \\
\hline
\end{tabular}

Table (13) presents the values of body angles during selecting time moments of compound skill performance for reception and passing with inside foot. The reception moment highest value was for right knee angle of the sixth player ( $V Y .091) \quad$, the lowest value was for right knee angle of the seventh player (94.403). During swinging moment, the highest value was for right speed was (0.038) for body mass center, at the collision moment of compound motor performance, direct shooting while moving.

Presentation and discussion of results of body angles during selected time moments of research compound skill performances knee angle of the sixth player (159.711), and the lowest value was for right knee angle of the fourth player (98.014). During the passing moment, the highest value was for right thigh angle of the first player (151.243), and the lowest value was for right foot angle of the fifth player (99.794), for the compound skill performance, reception and passing with inside foot. 
Table (14)

Arithmetic mean, standard deviation, and highest/lowest values of body angles during maximal swinging moment of compound skill performance (direct shooting while moving by foot front)

\begin{tabular}{|c|c|c|c|c|c|c|c|c|}
\hline \multicolumn{4}{|c|}{ Collision moment } & \multicolumn{4}{|c|}{ Maximal swinging moment } & Time moments \\
\hline $\begin{array}{c}\text { Lowest } \\
\text { value }\end{array}$ & $\begin{array}{l}\text { Highest } \\
\text { value }\end{array}$ & $\varepsilon^{ \pm}$ & س - & $\begin{array}{c}\text { Lowest } \\
\text { value }\end{array}$ & $\begin{array}{c}\text { Highest } \\
\text { value }\end{array}$ & $\varepsilon^{ \pm}$ & س & $\begin{array}{c}\text { Anatomical } \\
\text { points }\end{array}$ \\
\hline $1 \leqslant .9 \vee \wedge$ & 181.077 & $1 . \mathrm{rr}$. & $10.00 \mathrm{~V}$ & $10 \leqslant .999$ & $\mid v 1 . \times 91$ & V.T. & ITr.To. & Right thigh angle \\
\hline $97 . \wedge 79$ & $|V r . \varepsilon V|$ & $r$ r. $\varepsilon l$. & Ir⿲. . VO & 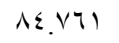 & $11 . .191$ & A.rut & $97 . \varepsilon \cdot Y$ & Right knee angle \\
\hline 1.1 .117 & $1 \leq \leqslant .0 \leqslant 7$ & $1 \leqslant .791$ & IYฯ. $\varepsilon \wedge \varepsilon$ & 1.0 .99 & 100.791 & $11 . r 00$ & $1 \leq 1, r \leq 1$ & Right foot angle \\
\hline $\begin{array}{l}\text { va } \\
\text { m } \\
\text { pe } \\
\text { wl } \\
\text { va } \\
\text { of } \\
\text { an } \\
\text { rig } \\
\text { pl } \\
\text { m } \\
\text { pe } \\
\text { wl } \\
\text { in } \\
\text { du }\end{array}$ & $\begin{array}{l}\text { Tabl } \\
\text { ues of } \\
\text { ximal } \\
\text { forming } \\
\text { ile mo } \\
\text { ue was } \\
\text { the fift } \\
\text { the lo } \\
\text { th thigh } \\
\text { yer } \\
\text { ximal } \\
\text { forming } \\
\text { ile mov } \\
\text { icates v } \\
\text { ing co }\end{array}$ & $\begin{array}{l}\text { (14) } \\
\text { oody a } \\
\text { swi } \\
\text { dire } \\
\text { ing. } \\
\text { or righ } \\
\text { play } \\
\text { vest v } \\
\text { angle o } \\
84.761 \\
\text { swi } \\
\text { dire } \\
\text { ng. Ta } \\
\text { lues o } \\
\text { lision }\end{array}$ & $\begin{array}{l}\text { shows } \\
\text { gles do } \\
\text { ging } \\
\text { she his } \\
\text { thigh a } \\
\text { (171.2 } \\
\text { the sev } \\
\text { ging do } \\
\text { le (14) } \\
\text { body ar } \\
\text { moment }\end{array}$ & $\begin{array}{l}\text { the } \\
\text { ing } \\
\text { of } \\
\text { ing } \\
\text { lest } \\
\text { gle } \\
1 \text { ), } \\
\text { for } \\
\text { nth } \\
\text { ing } \\
\text { of } \\
\text { ing } \\
\text { lso } \\
\text { ses } \\
\text { of }\end{array}$ & $\begin{array}{l}\text { perfo } \\
\text { while } \\
\text { highe } \\
\text { knee } \\
\text { (173. } \\
\text { value } \\
\text { of th } \\
\text { collis } \\
\text { perfo } \\
\text { while } \\
\text { Prese } \\
\text { of re } \\
\text { body } \\
\text { time } \\
\text { comp }\end{array}$ & $\begin{array}{l}\text { ming } \\
\text { mov } \\
t \text { valu } \\
\text { angle c } \\
471 \text { ), } \\
\text { was fo } \\
\text { sever } \\
\text { on } \\
\text { ming } \\
\text { moving } \\
\text { itation } \\
\text { ults } \\
\text { points } \\
\text { mome } \\
\text { ound s }\end{array}$ & $\begin{array}{l}\text { direct } \\
\text { ng, wl } \\
\text { was } \\
\text { and the six } \\
\text { right } \mathrm{k} \\
\text { th playe } \\
\text { momer } \\
\text { direct } \\
\text { and d } \\
\text { angul } \\
\text { during } \\
\text { its of } \\
\text { ill perf }\end{array}$ & $\begin{array}{l}\text { shooting } \\
\text { ere the } \\
\text { or right } \\
\text { th player } \\
\text { lowest } \\
\text { tee angle } \\
\text {, during } \\
\text { of } \\
\text { shooting } \\
\text { scussion } \\
\text { s speed } \\
\text { selected } \\
\text { research } \\
\text { rmances }\end{array}$ \\
\hline
\end{tabular}

Table (15)

Arithmetic mean, standard deviation, and highest/lowest values of angular speed body points during the time moment of reception for compound skill performance (Ball reception and passing)

\begin{tabular}{|c|c|c|c|c|c|}
\hline $\begin{array}{c}\text { Lowest } \\
\text { value }\end{array}$ & Highest value & $\varepsilon \pm$ & س س & variable & Time moment \\
\hline $0 \leqslant . \leqslant V \leqslant-$ & $r . . v \varepsilon$. & QV.YYI & AV.Yqะ & $\begin{array}{c}\text { Angular } \\
\text { speed of } \\
\text { right } \\
\text { thigh }\end{array}$ & \\
\hline V.OVI & $1 \leq . . Y \vee q$ & OV.TVY & $09.1 \leq 7$ & $\begin{array}{l}\text { Angular } \\
\text { speed of } \\
\text { right } \\
\text { knee }\end{array}$ & Reception moment \\
\hline
\end{tabular}

Assiut Journal For Sport Science Arts 
Follow Table (15)

Arithmetic mean, standard deviation, and highest/lowest values of angular speed body points during the time moment of reception for compound skill performance (Ball reception and passing)

\begin{tabular}{|c|c|c|c|c|c|}
\hline $\begin{array}{c}\text { Lowest } \\
\text { value }\end{array}$ & Highest value & $\varepsilon \pm$ & س - & variable & Time moment \\
\hline YVT. $\leqslant O \Lambda_{-}$ & 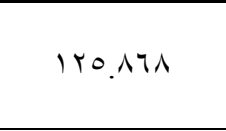 & 147.790 & $1 \cdot V Y \leq \Sigma_{-}$ & $\begin{array}{l}\text { Angular } \\
\text { speed of } \\
\text { right foot }\end{array}$ & \\
\hline ש מזד. & $r \leq V . Y \backslash \wedge$ & $11 \leq .0 .9$ & $119 . \wedge 1 \Lambda_{-}$ & $\begin{array}{c}\text { Angular } \\
\text { speed of } \\
\text { right thigh }\end{array}$ & \multirow{3}{*}{ Swinging moment } \\
\hline or. $v \leqslant V_{-}$ & VIT.ME & ए१.А.. & שT & $\begin{array}{c}\text { Angular } \\
\text { speed of } \\
\text { right knee } \\
\end{array}$ & \\
\hline$r \leq \varepsilon . \leqslant r \Lambda_{-}$ & סTRTM & $17 . .1 \leq \varepsilon$ & IV.09Y_ & $\begin{array}{l}\text { Angular } \\
\text { speed of } \\
\text { right foot }\end{array}$ & \\
\hline$|\vee \neg . \wedge \varepsilon|-$ & $|\pi| 1 \leq \varepsilon$ & سror.or & 9T.Orr_ & $\begin{array}{c}\text { Angular } \\
\text { speed of } \\
\text { right thigh }\end{array}$ & \multirow{3}{*}{ Passing moment } \\
\hline$r q 1 . \leq \leqslant 7$. & $\leqslant 91.017$ & 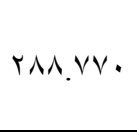 & rqA. rVo & $\begin{array}{c}\text { Angular } \\
\text { speed of } \\
\text { right knee }\end{array}$ & \\
\hline $1 \% \cdot .99 \cdot-$ & 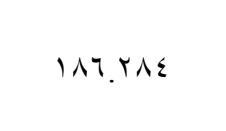 & I.r.r & $r \leq \leq 11$ & $\begin{array}{l}\text { Angular } \\
\text { speed of } \\
\text { right foot }\end{array}$ & \\
\hline
\end{tabular}

Table (15) indicates the values of angular speed body points during selected time moments of research compound skill performances during the time moment of reception for compound skill performance (Ball reception and passing). As for moment of reception, the highest angular speed was for right thigh of sixth player (200.740) m./sec., and the lowest angular speed was for right foot of seventh player (273.458) m./sec. The table also demonstrates the angular speed values of body points during swinging moment, in which the highest value was for right knee of first player (712.324) m./sec., and the lowest value was for right 
knee of sixth player $(-530.474)$ $\mathrm{m} . / \mathrm{sec}$. Concerning the moment of passing, the highest angular speed was for right knee of the first player (491.586) m./sec., and the

\section{Table (16)}

Arithmetic mean, standard deviation, and highest/lowest values of angular speed body points during the time moment of maximal swinging for compound skill performance (direct shooting while moving by foot front)

\begin{tabular}{|c|c|c|c|c|c|}
\hline $\begin{array}{c}\text { Lowest } \\
\text { value }\end{array}$ & Highest value & $\varepsilon^{ \pm}$ & 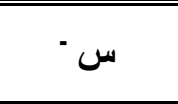 & & variables \\
\hline$r r \cdot . \leqslant O V_{-}$ & $\leq \leqslant \wedge .7 \leq 1$ & YYT.TVY & $179.00 r$ & $\begin{array}{l}\text { Angular } \\
\text { speed } \\
\text { of right } \\
\text { thigh } \\
\end{array}$ & \multirow{3}{*}{ Maximal swinging } \\
\hline EYr.YAO_ & $0 \leqslant \varepsilon . \varepsilon \cdot V$ & rYч.991 & $r \cdot . \Sigma 11-$ & $\begin{array}{l}\text { Angular } \\
\text { speed } \\
\text { of right } \\
\text { knee } \\
\end{array}$ & \\
\hline $119 \bar{r}^{-} . .9$ & ห৭..$\leqslant 7$. & $\leqslant 19 . r \leqslant \wedge$ & TAY.YTV_ & $\begin{array}{l}\text { Angular } \\
\text { speed } \\
\text { of right } \\
\text { foot }\end{array}$ & \\
\hline EVT.10Y. & 1.9 .017 & IY $\varepsilon . Y T$. & $r$ rq.q1.- & $\begin{array}{l}\text { Angular } \\
\text { speed } \\
\text { of right } \\
\text { thigh } \\
\end{array}$ & \multirow{3}{*}{ collision } \\
\hline OYI.TVT & $1091.0 Y V$ & $r V \leq . Y \leq T$ & q7ז.人זq & $\begin{array}{c}\text { Angular } \\
\text { speed } \\
\text { of right } \\
\text { knee } \\
\end{array}$ & \\
\hline or.991_ & $79 \leq .1 \times 9$ & $r \leqslant 1.99$ & . & $\begin{array}{c}\text { Angular } \\
\text { speed } \\
\text { of right } \\
\text { foot } \\
\end{array}$ & \\
\hline \multicolumn{3}{|c|}{$\begin{array}{l}\text { Table (16) indicates } \\
\text { angular speed values of body } \\
\text { points during time moments of }\end{array}$} & \multicolumn{3}{|c|}{$\begin{array}{l}\text { compound skill performance } \\
\text { (direct shooting while moving } \\
\text { with foot front). The highest }\end{array}$} \\
\hline
\end{tabular}

lowest angular speed was for the right knee of the sixth player (-305.486), during the skill performance (reception and passing with inside foot). passing moment of compound 
angular speed was for right knee of seventh player (544.407) m./sec., and the lowest angular speed was for right knee of the fourth player (-1192.009) m./sec. As for collision moment, the highest angular speed was for right knee of the sixth player (1591.527) m./sec., and the lowest angular speed was for

\section{Table (17)} Arithmetic mean, standard deviation, and highest/lowest values of
speed and displacement variables during selected time moments of
compound skill performance (Ball reception and passing with
inside of foot) $\mathrm{N}=7$ Arithmetic mean, standard deviation, and highest/lowest values of
speed and displacement variables during selected time moments of
compound skill performance (Ball reception and passing with
inside of foot) $\mathrm{N}=7$ Arithmetic mean, standard deviation, and highest/lowest values of
speed and displacement variables during selected time moments
compound skill performance (Ball reception and passing with
inside of foot) $\mathrm{N}=7$ Arithmetic mean, standard deviation, and highest/lowest values of
speed and displacement variables during selected time moments
compound skill performance (Ball reception and passing with
inside of foot) $\mathrm{N}=7$

\begin{tabular}{|c|c|c|c|}
\hline \multicolumn{3}{|c|}{ Total ball speed } & \multirow{2}{*}{$\begin{array}{c}\text { variables } \\
\text { Time } \\
\text { moment }\end{array}$} \\
\hline $\begin{array}{l}\text { Passing } \\
\text { moment }\end{array}$ & $\begin{array}{r}\text { Swinging } \\
\text { moment }\end{array}$ & Reception moment & \\
\hline$\overline{7 . \mu \cdot \Lambda}$ & T.90V & I.VOT & س - س \\
\hline 1.M & 1.509 & $\cdot r \cdot v$ & $\varepsilon^{ \pm}$ \\
\hline 1.019 & $\varepsilon .94$ & T. $. T \leq$ & Highest value \\
\hline$\varepsilon .71 \Lambda$ & $1 . \leq 71$ & $1 . Y \wedge \varepsilon$ & Lowest value \\
\hline .994 & $\cdot . \wedge r 7$ & $\because \cdot V \mu$ & س" \\
\hline. .191 &.. $\mathrm{VV}$ & 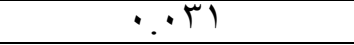 & $\varepsilon^{ \pm}$ \\
\hline $1 . r \leq 9$ & $1.1 \cdot V$ &. $.11 \mathrm{~V}$ & Highest value \\
\hline.$V \vee 0$ & $.71 \leq$ & $\because \mu \Lambda$ & Lowest value \\
\hline \multicolumn{2}{|c|}{$\begin{array}{l}\text { Table (17) shows that } \\
\text { the highest speed value of ball } \\
\text { as a shot was }(8.589) \mathrm{m} . / \mathrm{sec} \text {., } \\
\text { achieved by the first player } \\
\text { during the moment of passing, } \\
\text { whereas the lowest speed value } \\
\text { of ball as a shot was ( } 1.284) \\
\text { m./sec., achieved by the sixth } \\
\text { player. The table also shows } \\
\text { that the highest displacement } \\
\text { value of ball as a shot was }\end{array}$} & \multicolumn{2}{|c|}{$\begin{array}{l}\text { (1.249) cm., achieved by the } \\
\text { fourth player at the passing } \\
\text { moment, and the lowest } \\
\text { displacement value of ball as a } \\
\text { shot was }(0.038) \mathrm{cm} \text {., achieved } \\
\text { by the third player at the } \\
\text { reception moment of } \\
\text { compound skill performance } \\
\text { (reception and passing with } \\
\text { inside foot). }\end{array}$} \\
\hline \multicolumn{4}{|c|}{ Assiut Journal For Sport Science Arts } \\
\hline
\end{tabular}

right thigh of sixth player (476.152) m./sec., in moment of collision of compound skill performance (direct shooting while moving).

Presentation and discussion of results of biomechanical variable values for ball as a shot during selected time moments of research compound skill performances 
Table (18)

Arithmetic mean, standard deviation, and highest/lowest values of speed and displacement variables during selected time moments of compound skill performance (Ball shooting while moving with foot front) $N=7$

\begin{tabular}{|c|c|c|c|c|}
\hline \multicolumn{2}{|c|}{ collision } & \multicolumn{2}{|c|}{ Maximal swinging } & Time moment \\
\hline $\begin{array}{c}\text { Total ball } \\
\text { displacement }\end{array}$ & $\begin{array}{c}\text { Total ball } \\
\text { speed }\end{array}$ & $\begin{array}{c}\text { Total ball } \\
\text { displacement }\end{array}$ & $\begin{array}{c}\text { Total ball } \\
\text { speed }\end{array}$ & variables \\
\hline 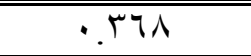 & $7 .+Y \Lambda$ & $\because .19$ & r.197 & س \\
\hline..$M T$ & 1.99. & $\because 0$ & $1 . \cdot \leq V$ & $\varepsilon^{ \pm}$ \\
\hline .7 .0 & A.OVY &. .111 & $\varepsilon . Y \cdot T$ & Highest value \\
\hline. .194 & r.Ts & $\because \cdots$ & 1. & Lowest value \\
\hline
\end{tabular}

Table (18) indicates that the highest value of ball as a shot was (8.572) m./sec., achieved by the fourth player during the moment of collision, whereas the lowest value of ball as a shot was (1.360) $\mathrm{m} . / \mathrm{sec}$., achieved by the fourth player at the moment of swinging. The highest value of ball as a shot displacement was $(0.605) \mathrm{cm}$., achieved by the sixth player during collision moment, whereas the lowest value of ball as a shot displacement was $(0.000) \mathrm{cm}$., achieved by players from first to sixth at the moment of maximal swinging of the compound skill performance, direct shooting while moving by foot front.

\section{Conclusions}

- The researchers recognized biomechanical variables (time- speed- displacement - angular speed- path of body mass center) for the current research compound skill performances.

- The path of body mass of the compound skill of the current research.

- The angles of anatomical points increase and decrease during time moments of the compound performances of the current research.

- There are differences in horizontal distance related to the increase in thigh angle during the moment of swinging and maximal swinging in each of the current research compound skill performances.

- A player needs high speed at the moment of collision in order to shoot the ball in an appropriate speed and displacement. 
- Increasing performance speed leads to a reduction in time of the dual stage and compound motor performance.

\section{Recommendations}

- The necessity of taking guidance from scientific bases in setting and designing programs that are related to instructing compound skill performances and developing the standard of skill performance.

- The necessity of instructing and training young soccer at skills based on biomechanical variables for developing speed, and displacement, as well as improving skill functional efficiency of young soccer.

- The necessity of designing training programs aiming at improving body joints' working during ball reception, passing, and shooting, and increasing speed rate of body joints during ball reception, passing, and shooting, whereas decreasing joints' speed during maximal swinging.

\section{References First: Arabic References}

1- El-Bassati, Amr-Allah Ahmad (1994): An analytical study of types of compound skill performances that are included in some team games during matches, Faculty of Physical Education in Abu Keer, Alexandria University.
2- El-Bassati, Amr-Allah Ahmad (1998): An analytical study for specifying the components of ability for skill performance in soccer. Journal of Theories \& Applications, Faculty of Physical Education, Alexandria University.

\section{3- Alaa El-Deen, Gamal} (1979): A study of some kinematic indicators of soccer kick (kicking a static ball by middle foot front as a model), A published article, Journal of Studies , Faculty of Physical Education, Helwan University.

4- Alaa EI-Deen, Gamal \& El-Sabbagh, Nahed (1995): Kinetics, unpublished notes, Faculty of Physical Education, Alexandria University.

\section{5- Alaa El-Deen, Gamal} (1994): A laboratorial study in biomechanics of sport movement, Faculty of Physical Education in Abu Keer, Alexandria University.

6- Ramadan, Raed Helmi (2001): An analytical study of compound skill performances and playing techniques, and their effect on game results in African Cup of Nations 2000, Scientific Journal of Research \& Studies, Faculty of Physical Education in Port Saeed, Suez Canal University.

7- Hassan, Zaki Muhammad (2004): Implications of Kinetics in sporting activity, an 
M.A. thesis, Egyptian Library, Alexandria.

8- Sulaiman, Sulaiman Farook (1993): The effect of a proposed technique for Instructing some Inclusive Skills on the Technical Standard of Young Soccerers, an M.A. thesis, Faculty of Physical Education in, Alexandria University.

9- Abdo, Sherif Ebraheem (1997): An analytical study of some Compound and Individual Skill Performances and their Relationship with Results of 1995 World Cup for Young Soccerers under 17 Years, an M.A. thesis, Faculty of Physical Education in Port Saeed, Suez Canal University.

10- Hussam El-Deen, Talha Hussein \& Abd El-Rahman, Ali Muhammad (1989): Sport Kinesiology of Motor Analysis, Dar El-Fekr ElArabi, Cairo.

11- Ali, Adel Abd El-Baseer (1998): Biomechanics \& Integration between Theory and Practice in Sport Field, $1^{\text {st }}$ ed., Book Distribution Center, Cairo.

12- Abd El-Haleem, Abd ElBasset \& Omar, Adel (2001): Setting Standard Levels of some Compound Skill Tests of Young Soccerers in A.R.E. Assuit Journal for Sciences and Arts of Physical Education,
Faculty of Physical Education for males, Assuit University, n. 13 , p. 1, November.

13- Abd El-Haleem, Abd ElBasset Muhammad (1998): The Effect of a Training Program for some Compound Skill Performances of Young Soccerers, an unpublished PH.D., Faculty of Physical Education, Alexandria University.

14- Eita, Amr Muhammad (2007): The effect of a proposed instructional program of some compound skill performances on skilled performance level of soccer school players, an unpublished M.A. thesis, Faculty of Physical Education, Mansoora University.

15- Eita, Amr Muhammad (2014): The effect of an instructional program based on some biomechanical indicators on compound movement level of young soccerers,. thesis, Faculty of Physical Education, Mansoora University.

16- Sultan, Muhammad Ebraheem (2004): The ratio of contribution of compound essential skills in performing some tactical principles for young soccerers, Journal of Theories \& Implications, vol.35, Faculty of Physical Education, Alexandria University. 
17- Hassan, Muhammad Abd El-Hameed (2002): Directing some biomechanical indicators for improving performance of direct free kick in soccer, an unpublished PH.D. thesis, Faculty of Physical Education, Zagazig University.

18- Mahmood, Muhammad Abd El-Sattar (2005): The effect of developing compound skill performances on some physical fitness components of young soccerers, an unpublished., Faculty of Physical Education, Mansoora University.

19- Abu Raya, Muhammad Abd El-Salam (1999): Designing a test battery for compound skill performances of soccer players in A.R.E. a PH.D. thesis, Faculty of Physical Education, Tanta University.

20- Keshk, Muhammad \& ElBassati, Amr-Allah (2000): Essentials of Tactical and skill preparation in soccer.

21- Radwan, M. Nasr ElDeen (2006): Introduction to measurement in sport and physical education, $1^{\text {st }}$ ed., Book Distribution Center, Cairo.

\section{Second: Foreign References}

1- Gissis and others (2006): Strength and speed characteristics of elite, subelite, and recreational young soccer players, sport medicine: an international journal.

2- Brown, Eugene W., Wilten, Winifred, \& Ahn, Byeong, (2013): Biomechanical comparison of the standard and handsprin soccer throw-in, school of health education, counseling psychology and human performance Michigan University.

3- Shan, Gongbing (2009): Biomechanical analysis of soccer kicking and passing - a synchronized analysis of $3 \mathrm{~d}$ kinematics and EMG, sport science association of Alberta (SSAA), through the asrpwf.

4- Marlene.J. Adrian \& John.

M. Cooper

(1995):

Biomechanics of Humman Movement, WCB. Brown, Benchmark, Communication, U.S.A.

Assiut Journal For Sport Science Arts 